\title{
Pemanfaatan Kalender 4M Sebagai Alat Bantu Meningkatkan Peran Serta Masyarakat dalam Pemberantasan dan Pencegahan Demam Berdarah
}

\author{
Titik Respati, ${ }^{1,2}$ Eka Nurhayati, ${ }^{2}$ Mahmudah, ${ }^{3}$ Yudi Feriandi, ${ }^{2}$ Budiman, ${ }^{2}$ \\ Fajar Yulianto, ${ }^{2}$ Kince Sakinah ${ }^{2}$ \\ ${ }^{1}$ Pascasarjana Fakultas Kedokteran Universitas Padjadjaran, ${ }^{2}$ Bagian Ilmu Kesehatan Masyarakat \\ Fakultas Kedokteran Unisba, ${ }^{3}$ Puskesmas Tamansari Kota Bandung
}

\begin{abstract}
Abstrak
Upaya pemberantasan sarang nyamuk yang dikenal selama ini adalah gerakan $3 \mathrm{M}$, yaitu Menguras-MenutupMengubur. Program ini belum berjalan dengan optimal terbukti dengan masih tingginya insidensi DBD dan masih terjadi kejadian luar biasa. Dibutuhkan monitoring yang kuat untuk mencapai keberhasilan 3M. Penelitian ini bertujuan mempergunakan alat bantu berupa kalender 4M (Menguras-Menutup-Mengubur-Monitor) untuk dipergunakan sebagai alat monitoring dalam program pemberantasan sarang nyamuk. Penelitian ini merupakan penelitian kualitatif dengan metode studi kasus menggunakan teknik wawancara mendalam dan diskusi grup terfokus. Metode sampling yang digunakan adalah maximal variation sampling dengan teknik analisis triangulasi. Informan berasal dari Dinas Kesehatan Kota Bandung, Puskesmas Tamansari, dan Kader Kesehatan di Kelurahan Tamansari selama bulan Juli 2015. Berdasarkan analisis data didapatkan bahwa masalah yang terjadi adalah pengabaian aktivitas rutin seperti $3 \mathrm{M}$ karena tidak terdapat mekanisme monitoring dan feedback. Salah satu keunggulan yang ada di lingkungan adalah motivasi dan partisipasi kader. Simpulan, kalender $4 \mathrm{M}$ berhasil dikembangkan sebagai sarana monitoring sekaligus edukasi untuk masyarakat. Kalender 4M merupakan alat bantu yang memfasilitasi keberadaan kader dalam mendukung program $3 \mathrm{M}$.
\end{abstract}

Kata kunci: Alat monitoring, kalender 4M, partisipasi masyarakat

\section{M Calendar Developmet for Monitoring Tools to Increase Community Participation in the Dengue Control Program}

\begin{abstract}
Dengue prevention program in Indonesia, $3 \mathrm{M}$, Menguras-Menutup-Mengubur have not been optimal as can be seen from the still high cases of dengue and some outbreak in several areas. A good monitoring process is needed to ensure the success of this program. This study aimed to develop monitoring tools to assist monitoring process in dengue prevention program. This was a qualitative study with case study approach using in-depth interview and focus group discussion with informants from Bandung City Health Department, Tamansari Health center and community cadres on July 2015. Sample method used was maximal variation sampling with triangulation analysis method. Results showed community participation hindered by the lack of monitoring and feedback tools. On the other hands participations from cadres were good that can be used to support $3 \mathrm{M}$ program. In conclusion, to assist the monitoring process, a tool-4M (Menguras-Menutup-Mengubur-Monitor) calendar-is developed to assist health cadres in supporting $3 \mathrm{M}$ program through monitoring process as well as for education purposes. A strong commitment and collaboration between cadres and community is needed to ensure the success of $3 \mathrm{M}$ program.
\end{abstract}

Key words: Community participation, monitoring tools, $4 \mathrm{M}$ calendar 


\section{Pendahuluan}

Demam berdarah dengue atau $\mathrm{DBD}^{1}$ merupakan masalah kesehatan masyarakat yang paling penting. ${ }^{2}$ Penyakit ini transmisinya dipengaruhi tidak hanya oleh karena proses dasar fisikal dan biologis misalnya perubahan iklim serta tingkat virulensi, tetapi juga oleh faktor sosioekonomi dan budaya. Faktor status ekonomi dan pola pekerjaan berpengaruh pada paparan maupun keparahan penyakit DBD tersebut.3.4 Aktivitas pembangunan tidak terencana, daya dukung lingkungan berkurang, penampungan air dan sanitasi dasar tidak layak, serta pola hidup masyarakatnya yang berubah semakin meningkatkan transmisi. ${ }^{5,6}$ Selain itu, terdapat faktor-faktor risiko lain yang disebabkan oleh perubahan demografis suatu wilayah, yaitu pemukiman di daerah perkotaan yang semakin padat, juga sistem transportasi yang semakin baik yang menyebabkan mobilitas penduduk semakin tinggi, serta tingkat urbanisasi yang sulit dikontrol. 7,8

Secara umum upaya pemberantasan sarang nyamuk (PSN) di Indonesia merupakan aktivitas utama upaya pencegahan DBD yang melibatkan peran serta masyarakat. Program ini mulai dijalankan sejak tahun 1992 dengan gerakan 3M, yaitu Menguras-Menutup-Mengubur. Program ini sudah berjalan selama lebih dari 20 tahun, akan tetapi belum berjalan dengan optimal terbukti dengan insidensi DBD yang tinggi dan masih terdapat kejadian luar biasa (KLB). ${ }^{1,9,10}$

Pemerintah Indonesia telah melakukan upaya pencegahan dan pengendalian DBD, akan tetapi upaya tersebut sampai saat ini masih belum berjalan efektif. Kendala yang dihadapi terutama karena masih minimnya partisipasi masyarakat yang merupakan kunci utama atas keberhasilan program ini. ${ }^{6,11,12}$ Program yang sudah lama dilakukan sering kali tidak berjalan dengan optimum oleh karena terdapat faktor kejenuhan dan rutinitas yang sering kali tidak mendapat perhatian. Memahami akan pentingnya faktor yang akan memengaruhi peran serta masyarakat dengan bentuk aplikasi program PSN yang paling tepat diharapkan dapat meningkatkan partisipasi mereka untuk keberhasilan sebuah program..$^{1,4,10,13}$

Model PSN yang akan menyempurnakan program 3M itu dikembangkan dengan melalui penggunaan alat bantu kalender $4 \mathrm{M}$ terdiri atas Menguras-Menutup-Mengubur-Monitoring.
Penggunaan alat bantu untuk meningkatkan partisipasi masyarakat dalam sebuah program ternyata sudah terbukti berhasil dalam beberapa program, misalnya penggunaan Kartu Menuju Sehat atau KMS untuk memantau pertumbuhan serta perkembangan anak. Model $4 \mathrm{M}$ tersebut dengan menggunakan kalender $4 \mathrm{M}$ dan sistem monitoring akan diujicobakan untuk membantu masyarakat berperan lebih aktif dalam program PSN.

Penelitian ini bertujuan mengembangkan alat bantu berupa kalender 4M untuk dipergunakan sebagai alat monitoring dan sekaligus edukasi dalam program pemberantasan sarang nyamuk (PSN). Pengembangan peran serta masyarakat dengan dukungan alat bantu kalender $4 \mathrm{M}$ itu dan sistem monitoring yang terpadu diharapkan mampu memberikan daya ungkit dalam upaya menanggulangi masalah DBD di Kota Bandung.

\section{Metodologi}

Penelitian ini merupakan penelitian kualitatif dengan metode studi kasus. ${ }^{14}$ Pengambilan data dilakukan mempergunakan teknik wawancara mendalam, observasi, dan diskusi grup fokus terhadap informan terpilih yang terlibat dalam program DBD. Diskusi grup fokus dilaksanakan oleh peserta dari latar belakang dan karakteristik yang sama, yaitu kader kesehatan. Wawancara mendalam dilaksanakan memakai instrumen pedoman wawancara tidak terstruktur.

Pendekatan yang dilakukan adalah dengan maximal variation sampling serta informan dipilih berdasarkan perbedaan perspektif atas topik yang akan diteliti. Ketika peneliti telah mendapatkan saturasi data yang diperlihatkan dengan tidak terdapatnya informasi baru dari para informan maka tahap pengambilan data kualitatif dianggap telah selesai.

Pengambilan data penelitian dilaksanakan selama bulan Januari sampai Februari 2015. Subjek penelitian adalah pemegang Program Pencegahan dan Penanggulangan Penyakit Menular dari Dinas Kesehatan Kota Bandung serta kader kesehatan yang aktif di wilayah kerja Kelurahan Tamansari, Kecamatan Bandung Wetan, Kota Bandung. Semua peneliti lalu mendiskusikan hasil yang didapatkan secara internal untuk mengembangkan alat bantu yang akan dipakai sebagai alat monitoring kegiatan PSN. Hasil penelitian ini akan dijadikan sebagai dasar pembuatan alat bantu program pencegahan dan 
pemberantasan demam berdarah.

Analisis data penelitian ini dilaksanakan dengan metode triangulasi. Pemikiran dasar penggunaan triangulasi itu adalah pengukuran akan semakin baik dan valid apabila beberapa indikator dipergunakan untuk mengukur hal yang sama. ${ }^{14}$ Semakin berbeda indikator yang dipakai mengukur dan tetap memperlihatkan hasil pengukuran yang identik akan semakin meningkatkan kepercayaan dan memberikan validitas yang lebih besar dibandingkan dengan apabila hanya satu metode pengukuran. Data dianalisis mempergunakan content analysis, yaitu proses menghitung secara objektif dan sistematis untuk dapat menghasilkan gambaran deskriptif dari isi teks. Content analysis dipilih karena tema utama telah diketahui sebelumnya. ${ }^{14}$

Untuk dapat membantu masalah monitoring dan juga evaluasi maka peneliti membangun Kalender 4M sebagai alat bantu dalam bentuk seperti pada gambar. Nama 4M dipilih untuk menyatakan kegiatan $3 \mathrm{M}$ yang diperkuat lagi dengan kegiatan Monitoring (4M). Kalender ini berisi informasi mengenai tanggal dan hari dilakukannya tindakan 4M, serta tempat-tempat penampungan air yang harus selalu diamati dan juga dibersihkan setiap minggu. ${ }^{5}$ Bentuk kalender dipilih berdasarkan pemikiran bahwa kalender masih dimanfaatkan secara harian oleh masyarakat untuk menentukan aktivitasnya. Selain itu, kalender memberikan ruang untuk sarana edukasi mengenai DBD. 4,6

\section{Hasil}

Hasil penelitian menunjukkan bahwa terdapat tiga faktor utama yang memengaruhi program DBD di Kota Bandung. Faktor-faktor tersebut adalah faktor input, proses, dan faktor eksternal. Faktor input terdiri atas kebijakan pencegahan dan penanggulangan demam berdarah dengue, sumber daya manusia, sistem pembiayaan, sarana, waktu, dan sistem informasi kesehatan. Faktor proses adalah segala bentuk kegiatan, prosedur, dan teknik yang dipergunakan untuk melakukan program DBD, yaitu terdiri atas perencanaan, implementasi dalam bentuk kegiatan, serta evaluasi. Faktor eksternal terdiri atas masyarakat, pemerintah daerah, dan agen penyebab demam berdarah dengue.

Berdasarkan analisis data, diketahui bahwa faktor input itu merupakan salah satu faktor yang memengaruhi program $4 \mathrm{M}$. Faktor input terdiri atas kuatnya kebijakan pencegahan dan penanggulangan DBD, jumlah dan kualitas sumber daya manusia, jumlah anggaran yang dialokasikan, sarana yang tersedia dan laik pakai, waktu yang dapat tersedia, serta sistem informasi kesehatan. Penyakit DBD merupakan penyakit menular yang menjadi salah satu masalah kesehatan di Kota Bandung. Kejadian DBD hampir selalu tinggi sepanjang tahun, namun paling tinggi tercatat pada trimester 1 hingga trimester ke-2. Sejak tahun 2007 Program Pencegahan dan Penanggulangan Demam Berdarah yang awalnya dipegang oleh Program Pemberantasan Penyakit Menular (P2M), kini menjadi tanggung jawab Program Pemberantasan Penyakit (P2P).

Alasan yang mendasari hal tersebut adalah kejadian penyakit menular maupun yang tidak menular atau double burden yang tinggi di Kota Bandung. Dengan ditambahkan Program Penyakit Tidak Menular, tidak hanya mengubah struktur organisasinya, akan tetapi juga terjadi pertambahan program, kegiatan, anggaran, dan beban kerja. Perubahan struktur organisasi itu akan membawa beberapa keuntungan, yaitu kemudahan dalam hal koordinasi dan analisis data seperti yang diungkapkan oleh narasumber 1 berikut ini:

"Kalau selama ini kan yang tidak menular itu kan tidak kita ketahui, datanya tidak kita ketahui, juga tidak kita laksanakan kan jadi untuk sekarang ini karena penyakit menular dan tidak menular sudah dalam satu bagian atau satu bidang sehingga itu lebih mengenakkan bagi kita untuk koordinasi." (Narasumber 1)

Konsekuensi penting dari perubahan struktur organisasi itu dengan ditambahkannya Program Pemberantasan Penyakit Tidak Menular ke dalam P2P adalah bertambahnya beban kerja tenaga kesehatan di Dinas Kesehatan Kota Bandung dan juga di puskesmas seluruh Kota Bandung. Pertambahan beban kerja ini harus diimbangi dengan pertambahan kuantitas dan kualitas tenaga kesehatan.

Tenaga kesehatan yang mempunyai tanggung jawab terhadap Program Pencegahan dan Penanggulangan Demam Berdarah Dengue di Dinas Kesehatan Kota Bandung saat ini terdiri atas 1 (satu) orang programmer dan beberapa orang koordinator lapangan, sementara itu di puskesmas, petugas yang mempunyai tanggung 
jawab terhadap demam berdarah dengue (DBD) hanya seorang. Programmer bertugas sebagai petugas surveilans DBD, sedangkan koordinator lapangan bertugas untuk pertanggungjawaban jadwal, peralatan, dan segala macam kebutuhan masyarakat di lapangan.

Tenaga kesehatan lain yang turut membantu di lapangan adalah enam tim tenaga kesehatan honorer yang bertanggung jawab dalam kegiatan fogging. Tim ini bekerja pada hari Senin sampai dengan Sabtu sesuai dengan waktu pelayanan puskesmas. Tim ini juga dapat bekerja sama berdasarkan kesepakatan dengan masyarakat.

Kejadian demam berdarah dengue dicatat dan dilaporkan melalui sistem informasi yang berjenjang yang disebut Sistem Kewaspadaan Dini. Informasi data diperoleh puskesmas dari pencatatan dan pelaporan dari balai pengobatan puskesmas dan laporan dari kader. Informasi tersebut kemudian diolah menjadi data dan dikirimkan ke Dinas Kesehatan Kota Bandung secara rutin baik mingguan maupun bulanan.

Data lainnya diperoleh berdasar akumulasi data dari seluruh rumah sakit di Kota Bandung, juga dari laporan langsung masyarakat. Data kemudian dicatat oleh petugas surveilans yang akan melakukan penyelidikan epidemiologis dan survei di lapangan.

Kegiatan pencegahan DBD telah dilakukan dengan berbagai cara. Kegiatan tersebut antara lain penyuluhan kepada masyarakat luas dan sosialiasi program kepada tokoh masyarakat. Penyuluhan mengenai DBD kepada masyarakat dilakukan dengan beberapa cara. Media yang digunakan selama ini adalah media elektronik seperti televisi dan radio serta media cetak seperti poster dan juga leaflet. Cara lain yang digunakan adalah penyuluhan secara langsung dengan cara mengumpulkan masyarakat.

Penyuluhan menggunakan media cetak dan elektronik telah dinilai oleh narasumber kurang efektif dalam upaya meningkatkan pengetahuan, sikap, dan juga perilaku masyarakat. Penyuluhan yang cukup efektif adalah penyuluhan secara langsung karena masyarakat dapat langsung bertanya dan mengupas segala aspek mengenai DBD. Hal ini dapat dilihat pada pernyataan berikut ini:

"Kalau menurut saya untuk ke masyarakat kalau sampai saat ini lebih efektif kalau penyuluhan langsung. Karena di bulan kemarin saja saya melakukan pertemuan.
Pertemuannya itu sebenarnya intinya untuk sosialisasi tentang fogging. Tapi kan kalau dengan pertemuan secara langsung itu halhal yang kira-kira bisa mereka tanyakan yang tidak paham itu bisa langsung ditanyakan." (Narasumber 1)

Meskipun kegiatan penyuluhan telah sering dilakukan, namun jumlah kejadian DBD tetap tinggi di Kota Bandung terutama pada bulan Januari-Februari pada saat musim penghujan. Keadaan ini disebabkan oleh penyuluhan belum mampu untuk meningkatkan kesadaran dan juga menstimulasi perubahan sikap dan perilaku masyarakat. Dinas Kesehatan Kota seolah-olah bekerja sendiri tanpa keterlibatan masyarakat.

Demam berdarah dengue (DBD) merupakan penyakitmenularyangberbasispadalingkungan. Pencegahan penyakit ini sangat bergantung pada sanitasi dan higienitas lingkungan yang terjaga. Upaya kegiatan pemberantasan sarang nyamuk dilaksanakan melalui pemberdayaan masyarakat. Masyarakat diminta untuk gotongroyong bekerja membersihkan lingkungan.

Kegiatan ini akan berjalan efektif dalam pencegahan DBD apabila dilaksanakan secara serentak di seluruh Kota Bandung. Berdasarkan alasan tersebut, tahun depan Kota Bandung akan menjalankan program GERTAK PSN yang merupakan singkatan dari Gerakan Serentak Pemberantasan Sarang Nyamuk. Program ini akan mendukung program kesehatan lingkungan lainnya yang sudah ditetapkan terlebih dahulu oleh Pemerintah dan Walikota Bandung. Program tersebut antara lain adalah Program Jumat Bersih (Jumsih) dan Gerakan Pungut Sampah (GPS).

Kegiatan pemberantasan nyamuk dianggap sebagai kegiatan yang seharusnya paling efektif dalam memutuskan rantai penularan penyakit DBD. Hambatan yang dialami adalah tidak ada tokoh masyarakat yang mampu menggerakkan warganya. Sejauh ini, RT atau RW belum dapat diandalkan sebagai tokoh penggerak kegiatan ini.

Fogging dilakukan untuk dapat membunuh nyamuk dewasa. Kegiatan fogging dilaksanakan apabila terdapat laporan baik dari masyarakat, puskesmas, ataupun rumah sakit bila terdapat penderita DBD di suatu lingkungan. Berdasarkan laporan tersebut maka petugas surveilans akan melakukan penelitian epidemiologis dan survei lingkungan. Fogging diklasifikasikan sebagai 
kegiatan untuk dapat mencegah penularan jika terbukti sudah ada masyarakat yang terkena DBD sehingga dikategorikan sebagai kegiatan pemberantasan DBD. Idealnya kegiatan ini dilakukan dalam golden period, yaitu 1x24 jam sampai dengan 1 minggu setelah ditemukannya kasus positif demam berdarah dengue. Dalam golden period tersebut, fogging dilakukan dua kali untuk mencapai efektivitas.

Hambatan yang dialami selama ini adalah keterlambatan laporan dari masyarakat ataupun puskesmas sehingga sudah melewati golden period, penolakanfogging dari masyarakat, serta permintaan fogging yang tidak sesuai dengan prosedur. Masyarakat sering kali meminta fogging padahal di lingkungannya belum ada kasus positif demam berdarah dengue sehingga pihak Dinas Kesehatan tidak dapat mengabulkan permintaan tersebut. Hal ini disebabkan oleh pengetahuan masyarakat mengenai Program Pencegahan dan Pemberantasan DBD kurang.

Evaluasi dan monitoring mengenai Program Pencegahan dan Pemberantasan DBD, termasuk program 3M Plus dilaksanakan secara rutin setiap tahun. Proses untuk evaluasi setiap tahun melibatkan peserta yang berbeda-beda seperti tampak pada pernyataan di bawah ini:

"Kita biasanya tapi tahun itu ada evaluasi cuman pesertanya kadang beda-beda, mungkin tahun ini pesertanya dari rumah sakit-rumah sakit dan puskesmas, tahun depan mungkin perwakilannya masyarakat." (Narasumber 1)

Hingga saat ini, Program Pencegahan dan Pemberantasan DBD termasuk 3M dianggap belum memenuhi unsur efektif, efisien, kualitas, dan keberlangsungannya. Faktor penghambat antara lain pemantauan yang kurang serta tidak ada tokoh penggerak masyarakat. Monitoring dan evaluasi menjadi salah satu penentu dalam keberhasilan program ini. Keberhasilan Program Pencegahan dan Pemberantasan DBD juga dipengaruhi oleh faktor eksternal yang terbagi menjadi tiga bagian besar, yaitu masyarakat, kebijakan dan juga dukungan dari pemerintah, serta karakter agen penyebab DBD.

Pengetahuan masyarakat mengenai DBD hingga saat ini dinilai sudah cukup walaupun masih ada beberapa bagian yang belum dipahami benar sepenuhnya oleh masyarakat. Masyarakat sudah mengetahui bahwasanya DBD merupakan penyakit yang dapat menyebabkan kematian sehingga kebanyakan masyarakat merasa takut jikalau ada anggota keluarga yang menderita penyakit ini. Hal yang belum diketahui oleh masyarakat adalah perbedaan cara pencegahan dengan pemberantasan sehingga cenderung mengandalkan fogging sebagai pencegahan. Hal lainnya yang juga belum diketahui masyarakat adalah fungsi dan prosedur fogging sehingga beberapa orang menolak dilakukannya fogging sementara yang lainnya terlambat mendapatkan fogging karena terlambat memberikan laporan.

Pengetahuan yang baik tidak berbanding lurus dengan kesadaran dan sikap masyarakat mengenai DBD. Masyarakat umumnya sudah banyak mengetahui bahwa pencegahan DBD harus berbasis masyarakat, namun masih ada beberapa bagian dari masyarakat yang menolak untuk didampingi oleh kader dan juga menolak untuk bekerja sama membersihkan lingkungan.

"Ngasih pengertian sudah, di depan kita mereka iya, ngerti-ngerti tapi di belakang kita ah kayak hidupnya sendiri sudah bersih gitu Bu." (Narasumber 3)

"Iya, nah itu kadang-kadang mereka gitu buang sampah sembarangan yang ngontrak itu, yang kos itu Bu yang saya khawatirkan yang kos itu kadang-kadang ok lah ngga usah bayar sampah tapi kita rapih jaga kebersihan." (Narasumber 4)

"Kadang-kadang kita ngelarang hari ini ok lah besoknya kambuh lagi.” (Narasumber 5)

Pengetahuan yang cukup serta sikap dan perilaku yang masih kurang tersebut disebabkan oleh keterlibatan para tokoh masyarakat yang kurang yang seharusnya berperan sebagai tokoh penggerak masyarakat. Hal ini menyebabkan Program Pencegahan dan Pemberantasan DBD tidak efektif seperti Program Pemberantasan Sarang Nyamuk. Hal ini tampak pada pernyataan di bawah ini:

"Salah satunya itu tadi mungkin dari penyuluhan kurang, yang keduanya masyarakat sendiri, ya kalau dimasyarakatkan ranahnya mungkin dari $R T, R W$, tokohmasyarakatketerlibatannya sendiri mungkin dalam gerakan masyarakat untuk pemberantasan sarang nyamuk itu juga masih kurang karena kan bisa bergerak kalau kita di sini kan dari tokoh masyarakat dari 


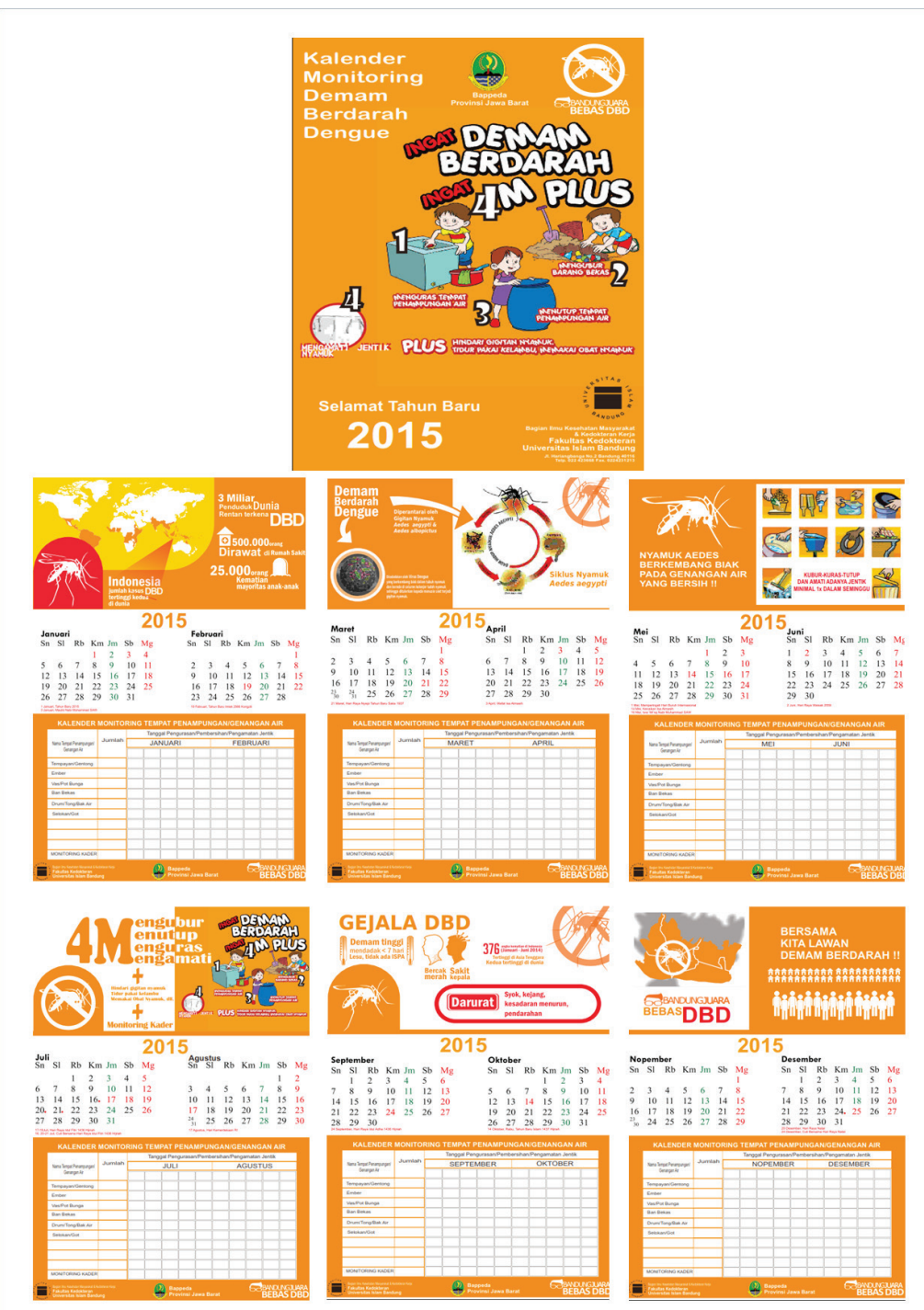

Gambar Kalender 4M

$R T, R W$, nah kalau misalkan dari RT-RT atau kelurahan kurang menggerakkan masyarakat tentunya kegiatan yang PSN juga kurang jalan." (Narasumber 1)

Faktor lainnya adalah keterlibatan kader dalam Program Pencegahan dan Pemberantasan DBD yang kurang. Di Kelurahan Tamansari ditemukan bahwa keadaan ini disebabkan oleh pergantian kader hampir setiap tahun sehingga kader sulit untuk terlibat dalam program itu. Kader juga jarang mendapatkan penyegaran ilmu sehingga penyuluhan yang disampaikan hanyalah materi yang sama saja. Masyarakat menjadi cenderung bosan dan segan saat diberi penyuluhan.
Keuntungan yang didapat wilayah Kelurahan Tamansari terkait keterlibatan kader adalah motivasi kader yang tinggi untuk menyehatkan lingkungannya. Kader rela tidak mendapatkan imbalan terhadap segala kegiatan yang mereka lakukan demi kesehatan lingkungan yang tentu akan berimbas pada mereka sendiri. Potensi ini seharusnya dapat dimanfaatkan sebaik-baiknya untuk membantu masyarakat luas agar mandiri dalam upaya pencegahan dan pemberantasan penyakit menular.

Kalender ini diharapkan dapat memfasilitasi kader untuk mengaktualisasikan dirinya sesuai dengan motivasi dan potensi yang dimilikinya. Fungsi utama kader dalam penerapan kalender ini seperti sebagaimana yang dibuktikan dalam 
penelitian di Indonesia dan Thailand adalah sebagai kolaborator yang mampu melakukan kunjungan secara teratur dan melakukan follow up terhadap sikap dan perilaku masyarakat. ${ }^{11,12}$ Para kader juga dapat berfungsi sebagai asisten dan pendukung yang membantu menghapus barrier komunikasi masyarakat dengan peneliti ataupun dengan petugas kesehatan. ${ }^{10,13}$

Kalender 4M adalah alat bantu yang dapat mempermudah proses edukasi dan monitoring. Penerapan kalender 4M tersebut membutuhkan kerjasama yang sangat baik antara kader dan masyarakat. Masyarakat harus sadar, mau, dan mampu berpartisipasi aktif. Hambatan yang dialami sejak awal adalah terdapat beberapa warga masyarakat yang tidak terbuka menerima kehadiran kader. ${ }^{7}$ Hal ini menunjukkan bahwa masih dibutuhkan penguatan untuk meyakinkan masyarakat mengenai peranan para kader dalam meningkatkan derajat kesehatan masyarakat.

\section{Simpulan}

Penelitian berhasil mengembangkan alat bantu monitoring pemberantasan sarang nyamuk (PSN) dengan cara memperkuat kerjasama antara masyarakat dan partisipasi para kader kesehatan dengan alat bantu kalender 4M. Kalender 4M dapat digunakan sebagai sarana edukasi selain alat monitoring dalam Program Pemberantasan Sarang Nyamuk. Alat bantu ini masih memerlukan evaluasi untuk memastikan efektivitasnya.

\section{Ucapan Terima Kasih}

Penelitian ini sudah mendapatkan bantuan hibah dari Badan Penelitian Pengembangan dan Penerapan Ilmu Pengetahuan dan Teknologi (BP3IPTEK) Provinsi Jawa Barat No. 070/ Kep.02/BP3IPTEK/2015.

\section{Daftar Pustaka}

1. Kusriastuti R, Sutomo S. Evolution of dengue prevention and control programme in Indonesia. Dengue Bull. 2005 Dec;29:17.

2. WHO. Experts call for strong leadership to control vector-borne diseases worldwide. Phenomenal spread of dengue represents unique challenges for $21^{\text {st }}$ century. Geneva: WHO; 2014.
3. Arunachalam N, Tana S, Espino F, Kittayapong P, Abeyewickreme W, Wai KT, dkk. Eco-bio-social determinants of dengue vector breeding: a multifactorial study in urban and periurban Asia. Bull WHO. 2010 Mar;88(3):173-84.

4. Caprara A, Lima JW, Peixoto AC, Motta CM, Nobre JM, Sommerfeld J, dkk. Entomological impact and social participation in dengue control: a cluster randomized trial in Fortaleza, Brazil. Trans R Soc Trop Med Hyg. 2015 Feb;109(2):99105.

5. Nam VS, Kay B, Thi Yen N, Ryan P, Bektas A. Community mobilization, behaviour change and biological control in the prevention and control of dengue fever in Viet Nam. Dengue Bull. 2004;28S:57-61.

6. Stewart Ibarra AM, Luzadis VA, Borbor Cordova MJ, Silva M, Ordoñez T, Beltrán Ayala E, dkk. A social-ecological analysis of community perceptions of dengue fever and Aedes aegypti in Machala, Ecuador. BMC Public Health. 2014 Nov;44:1135.

7. Bazzani R, Wiese M. Poverty, ecosystem and vector-borne diseases: introduction. Dalam: Charron DF, penyunting. Ecohealth research in practice. Innovative applications of an ecosystem approach to health. New York: Springer; 2012. hlm. 133-7.

8. Andersson N, Nava-Aguilera E, Arosteguí J, Morales-Perez A, Harold Suazo-Laguna, Legorreta-Soberanis J, dkk. Evidence based community mobilization for dengue prevention in Nicaragua and Mexico (Camino Verde,the Green Way): cluster randomized controlled trial. BMJ. 2015 Jul;351:h3267.

9. Dinas Kesehatan Kota Bandung. Profil kesehatan Kota Bandung 2009. Bandung: Dinkes Kota Bandung; 2010.

10. Sommerfeld J, Kroeger A. Innovative community-based vector control interventions for improved dengue and Chagas disease prevention in Latin America: introduction to the special issue. Trans $\mathrm{R}$ Soc Trop Med Hyg. 2015 Feb;109(2):85-8.

11. Respati T, Darmawan D, Suryafitri Z. Pengetahuan dan peran tokoh masyarakat dalam pengendalian demam berdarah dengue di Desa Sukamanah dan Desa Rancaekek Wetan (diunduh 5 November 2015). Tersedia dari: http://documents. tips/documents/artikel-studi-kualitatif-dbd- 
128 Pemanfaatan Kalender 4M Sebagai Alat Bantu Meningkatkan Peran Serta Masyarakat

revisi.html?

12. Arunachalam N, Tyagi BK, Samuel M, Krishnamoorthi R, Manavalan R, Tewari SC, dkk. Community-based control of Aedes aegypti by adoption of eco-health methods in Chennai City, India. Pathog Glob Health. 2012 Dec;106(8):488-96.

13. Tana S, Abeyewickreme W, Arunachalam N, Espino F, Kittayapong P, Wai KT, dkk. Eco-bio-social research on dengue in Asia: general principles and a case study from Indonesia. Dalam: Charron DF, penyunting. Ecohealth research in practice. Innovative applications of an ecosystem approach to health. New York: Springer; 2012. hlm. 17384.

14. Creswell JW. Research design: qualitative, quantitative, and mixed method approaches. Edisi ke-4. London: SAGE Publication Inc.; 2009. 